\title{
Metabolic response to intravenous salbutamol therapy in acute asthma
}

\author{
T. R. TICKNER ${ }^{1}$, D. G. CRAMP 1 , A. Y. FOO ${ }^{1}$, A. J. JOHNSON ${ }^{4}$, S. M. BATEMAN ${ }^{3}$, \\ J. PIDGEON ${ }^{3}$, S. G. SPIRO ${ }^{3}$, S. W. CLARKE ${ }^{2}$, AND M. R. WIL.LS ${ }^{1}$
}

From the Departments of Chemical Pathology ${ }^{1}$ and Thoracic Medicine ${ }^{2}$, Royal Free Hospital, London NW3 and the Department of Medicine ${ }^{3}$ and Asthma Research Council Clinical Pharmacolog Unit ${ }^{4}$, Brompton Hospital, London SW3

Tickner, T. R., Cramp, D. G., Foo, A. Y., Johnson, A. J., Bateman, S. M., Pidgeon, J., Spiro, S. G., Clarke, S. W., and Wills, M. R. (1977). Thorax, 32, 182-184. Metabolic response to intravenous salbutamol therapy in acute asthma. In patients suffering from an acute attack of asthma the effects of salbutamol infusion $(10 \mu \mathrm{g} / \mathrm{min})$ on their plasma concentrations of non-esterified fatty acids (NEFA), triglyceride, insulin, and glucose were compared with those in a group of asthmatics not requiring infusion. Salbutamol was found significantly to increase the plasma concentrations of glucose and insulin while having little effect on NEFA or triglyceride. However, NEFA concentrations were found to be significantly increased in patients with an acute attack of asthma at the time of their admission to hospital. This increase is attributed to the stress of the asthmatic attack itself.

Increased plasma non-esterified fatty acid (NEFA) concentrations have been associated with myocardial arrhythmias (Oliver, 1972). Such increases have been reported to follow the intravenous injection in normal subjects of the $\beta_{2}$ sympathomimetic drug salbutamol (Goldberg et al., 1975). These findings led to the suggestion that this drug could be dangerous when used for asthmatic patients already subjected to the hypoxia and tachycardia of the disease itself (British Medical Journal, 1975; Goldberg et al., 1975). A clinical trial of salbutamol therapy (to be reported elsewhere) afforded us the opportunity to examine plasma NEFA concentrations, and those of associated metabolites, in relation to the intravenous use of this drug in asthma.

\section{Subjects and methods}

Thirty-six patients admitted with acute asthma, unresponsive to their usual treatment, were studied. All had a sample of venous blood collected before being treated with an initial standard regimen consisting of a single slow intravenous bolus of aminophylline $(5 \mathrm{mg} / \mathrm{kg})$ given while the patient received oxygen, and two administrations each of $5 \mathrm{mg}$ salbutamol by intermittent positive pressure breathing; there was a period of at least $15 \mathrm{~min}$ between each treatment. After the second dose of salbutamol $(1 \mathrm{~h}$ after the start of treatment) a second blood sample was collected Twenty patients in whom an adequate therapeutic response was obtained formed a control group and from these a further blood sample was collecteक $4 \mathrm{~h}$ after their admission. Sixteen patients who did not show an adequate therapeutic improvement 3 . as judged by the overall clinical response, were placed on an intravenous infusion of salbutamoB at the rate of $10 \mu \mathrm{g} / \mathrm{min}$. This group of patientso had further blood samples collected 1 and $4 \mathrm{~h}$ after the start of the infusion. At a later date, aftero resolution of the attack, a fasting blood sample was obtained from all patients.

The patients studied and the severity of thein asthma on admission are summarised in Table 1 N Eight of the control group and five of the infusiono group were taking oral prednisone before admission. Eighteen subjects in the control group and 15 in the infusion group were on regular salbuta@ mol medication. On admission to hospital corti costeroids were prescribed for all subjects excep 5 three of the control group. In the $4 \mathrm{~h}$ following the completion of the initial regimen neither groule received any bronchodilator therapy additiona? to the salbutamol given to the infusion group.

After collection, the blood samples were centrio 
Table 1 Details of patients on admission (mean $\pm S E M$ )

\begin{tabular}{|c|c|c|c|c|c|c|c|c|c|}
\hline \multirow[t]{3}{*}{ Group } & \multirow{3}{*}{$\begin{array}{l}\text { Age } \\
\text { (year) }\end{array}$} & \multirow{3}{*}{$\begin{array}{l}\text { Sex } \\
(M / F)\end{array}$} & \multirow{3}{*}{$\begin{array}{l}H t \\
(\mathrm{~cm})\end{array}$} & \multicolumn{6}{|c|}{ Values on admission } \\
\hline & & & & \multicolumn{3}{|c|}{ Arterial blood } & \multirow[b]{2}{*}{$\begin{array}{l}P E F R \\
(I / \min )\end{array}$} & \multirow[b]{2}{*}{$\begin{array}{l}H R \\
(b t / \min )\end{array}$} & \multirow[b]{2}{*}{$\begin{array}{l}R R \\
/ \mathrm{min}\end{array}$} \\
\hline & & & & $p H$ & $\begin{array}{l}\mathrm{Po}_{2} \\
(m m H g)\end{array}$ & $\begin{array}{l}\mathrm{PCO}_{2} \\
(\mathrm{~mm} H g)\end{array}$ & & & \\
\hline $\begin{array}{l}\text { Control } \\
\text { Salbutamol infusion }\end{array}$ & $\begin{array}{l}39 \\
\pm 3.9 \\
37 \\
\pm 3.9\end{array}$ & $10 / 10$ & $\begin{array}{l}168 \\
\pm 2 \cdot 2 \\
168 \\
\pm 2 \cdot 0\end{array}$ & $\begin{array}{l}7 \cdot 40 \\
\pm 0 \cdot 018 \\
7 \cdot 38 \\
\pm \\
0 \cdot 014\end{array}$ & $\begin{array}{c}61 \\
\pm 3 \cdot 2 \\
63 \\
\pm 2 \cdot 7\end{array}$ & $\begin{array}{l}38 \\
\pm 2 \cdot 0 \\
40 \\
\pm 1 \cdot 6\end{array}$ & $\begin{array}{c}111 \\
\pm 10 \cdot 2 \\
95 \\
\pm 8 \cdot 2\end{array}$ & $\begin{array}{l}108 \\
\pm 2 \cdot 9 \\
109 \\
\pm 3 \cdot 3\end{array}$ & $\begin{array}{l}24 \\
\pm 1 \cdot 3 \\
27 \\
\pm 2 \cdot 0\end{array}$ \\
\hline
\end{tabular}

PEFR = peak expiratory flow rate.

HR = heart rate (beats per minute).

RR = respiratory rate (breaths per minute).

fuged and the separated plasma was deep frozen $\left(-20^{\circ} \mathrm{C}\right)$ until analysis. NEFA was measured by the method of Carruthers and Young (1973), triglyceride by the method of Cramp and Robertson (1968), glucose using an automated glucose oxidation method (Trinder, 1969), and insulin by a single antibody radioimmunoassay (Lepetit).

Statistical analysis was performed using Student's unpaired $t$ test.

\section{Results}

The 20 subjects in the control group and the 16 allocated to salbutamol were all matched for age, sex, and height. Their arterial blood gas values, peak expiratory flow rate (PEFR), heart rate, and respiratory rate on admission were also similar (Table 1). After the initial standard regimen those subjects considered to have improved sufficiently not to require an intravenous infusion of salbutamol (the control group) had increased their PEFR from $1111 / \mathrm{min}(\mathrm{SEM} \pm 10 \cdot 2)$ to $2201 / \mathrm{min}$ (SEM $\pm 14 \cdot 3$ ), while those judged to have responded poorly (the salbutamol group) showed a smaller increase in PEFR, $951 / \mathrm{min}( \pm 8.2)$ to $1381 / \mathrm{min}$ (士9.0).

On admission mean plasma NEFA were elevated from the normal laboratory range $(<600$ $\mu \mathrm{mol} / 1)$ in both groups of patients and were significantly increased when compared with fasting values obtained after resolution of the asthma attack (Table 2). No further increase in NEFA occurred during the salbutamol infusion, nor did plasma triglyceride concentration alter (Fig. 1).

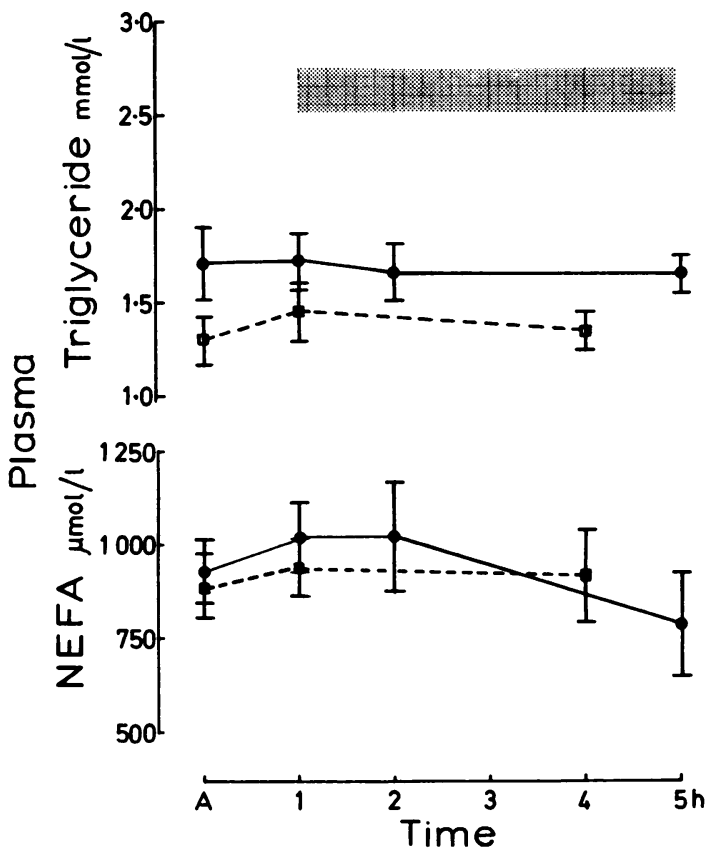

Fig. 1 Response of plasma NEFA and triglyceride to therapy in asthma. All values are mean $\pm S E M$. Closed circles represent patients receiving salbutamol by infusion. Open squares represent the 'control' group. The time of the infusion is indicated by the hatched area.

Following initial therapy the plasma insulin and glucose concentrations rose, the increase becoming significant for both variables only in the control

Table 2 Comparison of fasting values with those on admission (mean $\pm S E M$ )

\begin{tabular}{|c|c|c|c|c|}
\hline & $\begin{array}{l}N E F A \\
(\mu \mathrm{mol} / l)\end{array}$ & $\begin{array}{l}\text { Triglyceride } \\
(\mathrm{mmol} / \mathrm{l})\end{array}$ & $\begin{array}{l}\text { Insulin } \\
(\mu u n i t s / m l)\end{array}$ & $\begin{array}{l}\text { Glucose } \\
(\mathrm{mmol} / \mathrm{l})\end{array}$ \\
\hline $\begin{array}{l}\text { All patients on admission } \\
\text { All patients fasting and convalescent } \\
\text { P }\end{array}$ & $\begin{array}{l}861 \pm 53 \\
520 \pm 47 \\
<0.001\end{array}$ & $\begin{array}{l}1 \cdot 47 \pm 0 \cdot 1 \\
1 \cdot 34 \pm 0 \cdot 1 \\
\text { NS }\end{array}$ & $\begin{array}{l}14 \pm 3 \\
19 \pm 5 \\
\text { NS }\end{array}$ & $\begin{array}{l}5 \cdot 8 \pm 0 \cdot 3 \\
5 \cdot 1 \pm 0 \cdot 2 \\
\text { NS }\end{array}$ \\
\hline
\end{tabular}




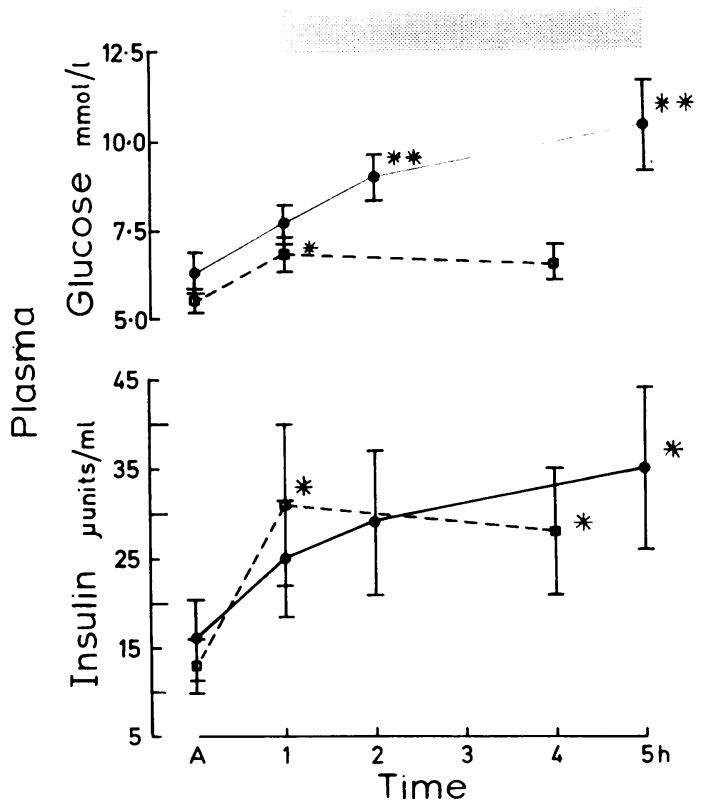

Fig. 2 Response of plasma glucose and insulin to therapy in asthma. Key as for Fig. 1: ${ }^{*} \mathrm{P}<0.05$, $* * \mathrm{p}<0.01$.

group (Fig. 2). However, during the infusion period there was a further sustained rise in the salbutamol group, which became significant when related to the admission values.

\section{Discussion}

The subjects included in the study did have severe asthma (Table 1), and the group who received the salbutamol infusion had shown a more limited improvement after the initial therapy of an intravenous aminophylline bolus and nebulised salbutamol.

Plasma NEFA concentration was raised to a similar extent in both groups of patients at the time of admission. Neither the initial treatment nor the salbutamol infusion caused any further rise in NEFA concentration. The failure of salbutamol to reproduce in the asthmatic patient the elevation of plasma NEFA seen in the normal subject suggests that either peripheral lipolysis is unaffected by the drug during the asthmatic attack, or that any increase is combated by increased NEFA utilisation. No increase in peripheral lipolysis would be observed were sympathomimetic activity at the adipose tissue receptor already maximal due to the disease itself. Alternatively, the elevation in plasma glucose and insulin concentrations may counter a rise in plasma NEFA concentration both by enhancing $\overrightarrow{\vec{\omega}}$ plasma NEFA uptake and by the action of insulin? on adipocyte hormone sensitive lipase.

Whatever the mechanism, it appears that fears $\frac{\bar{c}}{\bar{s}}$ expressed for the myocardium, based upon the $\underset{\mathbb{Q}}{\mathbb{Q}}$ NEFA response to salbutamol infusion in normal subjects (British Medical Journal, 1975; Goldberg et al., 1975), are unfounded when the drug is used in the treatment of acute asthma. Nevertheless, $\vec{\omega}$ plasma NEFA concentration was significantly $\omega_{\sigma}$ higher during the asthmatic attack than in the $\vec{x}$ same patients when used as their own fasting con- $\dot{\omega}$ trols. Since no difference was noted between ad- N mission and convalescent plasma concentrations of insulin, glucose, or triglyceride, it is unlikely $\mathbb{N}_{N}^{\infty}$ that dietary differences can explain those findings. 을 Furthermore, the convalescent patients were re- ceiving doses of steroids and bronchodilators $D$ equivalent to or greater than those before admission, so that changes in therapy do not explain the $\overrightarrow{0}$ differences. Therefore, it appears that the in- $y$ crease in NEFA observed in these patients was. related to the stress of the condition itself.

Thus changes in plasma NEFA concentration do not follow the intravenous infusion of salbutamolo during acute attacks of asthma and such changes do not contribute to the hazards of using this drug@ for this condition.

We thank the physicians at the Brompton Hospital for permission to study patients under their care.0. The nursing staff of Blunt Ward assisted in the collection of blood samples and data.

\section{References}

British Medical Journal (1975). Management of acutê asthma. (Leading article) British Medical Journal, 4, 65-66.

Carruthers, M. and Young, D. A. B. (1973). Free fatty acid estimation by a semiautomated fluori- $>$ metric method. Clinica Chimica Acta, 49, 341-348.

Cramp. D. G. and Robertson, G. (1968). The fluori metric assay of triglyceride by a semiautomatedo method. Analytical Biochemistry, 25, 246-251.

Goldberg, R., Van As, M., Joffe. B. I., Krut, L.N Bersohn, I., and Seftel. H. C. (1975). Metabolic responses to selective $\beta$-adrenergic stimulation in man. Postgraduate Medical Journal, 51, 53-58.

Oliver, M. F. (1972). Metabolic response during im pending myocardial infarction. II. Clinical implica? tions. Circulation, 45, 491-500.

Trinder, P. (1969). Determination of glucose in blood using glucose oxidase with an alternative oxygern acceptor. Annals of Clinical Biochemistry, 6, 24-27

Requests for reprints to: Dr. S. W. Clarke, Departo ment of Thoracic Medicine, Royal Free Hospital London NW3. 